\title{
FOOD SECURITY AND PERFORMANCE OF RICE AGRIBUSINESS INSTITUTIONS IN COASTAL AREAS OF SELUMA REGENCY
}

\author{
Sriyoto 1); (rnad ${ }^{2) ;}$ Bambang Sumantri ${ }^{3) ;}$ Basuki Sigit Priyono ${ }^{4)}$ \\ 1,2,3,4) Department of Agricultural Socio-Economics, Faculty of Agriculture, University of \\ Bengkulu \\ Email: ${ }^{1)}$ Sriyoto@unib.ac.id
}

\begin{abstract}
How to Cite :
Sriyoto, Irnad, B Sumantri, BS Priyono, 2020. Food Security And Performance Of Rice Agribusiness Institutions In Coastal Areas Of Seluma Regency. Journal of Agri Socio-Economics and Business. 2 (2): 69-84. DOI: https://doi.org/10.31186/jaseb.2.2.69-84
\end{abstract}

\section{ARTICLE HISTORY \\ Received [21 Dec 2020] \\ Revised [26 Dec 2020] \\ Accepted [30 Dec 2020]}

\section{KEYWORDS}

food security,

Agribusiness Institution, performance,

Rice

This is an open access article under the $C C-B Y$-SA license

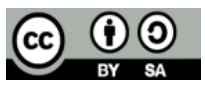

\section{ABSTRACT}

Food security in Indonesia has become a central issue in agricultural development and national development. The problem of food and food security cannot be separated from the context of rice. This is because rice is a staple food consumed by almost all Indonesians. Thus, the availability of rice is an important factor in strengthening national food security. The level of national food security, regional food security must be followed by the achievement of the level of resilience of villages, households and individuals. The role and performance of rice agribusiness institutions are important in the effort to achieve household food security for rice farmers. The objectives of this research are: 1) to analyze the food security level of farmers household; 2) to identify the determinants of food security level; 3) identifying the level of food security with the institutional performance of rice agribusiness. The results of this study indicate that the level of household food security is categorized as food resistance, the determinants of the level of food security are influenced by the number of family members and the income of rice farming. The food resistance category was followed by the institutional performance of PT. Pusri is very good, PT. Pertani is good, Bank of BRI is good, and farmer group institutions are moderate. 


\section{INTRODUCTION}

Food is an important and strategic commodity for Indonesia considering food is a basic human need that must be met by the government and society together. Food security in Indonesia has become a central issue in agricultural development and national development. The problem of food and food security cannot be separated from the context of the rice commodity. This is because rice is a staple food consumed by almost all people (Januar and Sumardjo, 2009). Thus, the availability of rice is a factor in strengthening national food security (Rusdiana and Maesya, 2017). According to Salim, et al (2004) that the development of food security in a country will be realized if the level of national and regional food security must be followed by the achievement of food security levels at the village, household and individual levels. This condition must still be followed by the good management of food stock.

The concept of rice farmer household food security can be measured or reflected through: a) the availability of paddy grain or household rice; b) the level of paddy grain stability or household rice; c) paddy grain access or farmer household rice; d) the utilization of paddy grain or rice by households, which is related to the frequency of eating (Januar and Sumardjo, 2009). Achievement of household food security will be influenced by the characteristics of the farmer household resources such as: the area of land owned, head of household formal education level, the level of farming experience, the number of family members and farm income.

In line with the increase in production as a positive impact of the application of technology and other inputs, various problems arise related to the production process, post-harvest, storage, transportation and marketing. This far the process of producing and handling crops has emphasized more on individual abilities and skills. Processes that involve agribusiness institutions, both in the form of formal and informal organizations, are generally still centered on the collecting and marketing process at a certain scale. For most regions, the existence of institutions.

The role of agribusiness and farmers or farmer groups has not been seen (Sadikin, et al, 2008). The functions and roles of agribusiness institutions are very diverse, including as a mobilizer, collector, distribution of production facilities, providers of capital, business financing, interest generator, attitudes and others.

Seluma Regency is the center of rice production in Bengkulu Province. Various agribusiness institutions that support the development of rice production include: PT. Pertani who provides and distributes good quality rice, PT. PUSRI provides and distributes fertilizer, BRI bank provides capital and financing for rice farming. This study aims to analyze the level of food security, to analyze the determinants of the level of food security with the institutional performance of rice agribusiness. 


\section{RESEARCH METHODS}

\section{Method of Location and Respondents Determination}

This research was conducted in Sukaraja and South Seluma sub regency, Seluma regency. Both locations are rice production centers and there are agribusiness institutions that are actively operating in supporting household food security for farmers in the area. The population of this study were lowland rice farmers and agribusiness institutions in the two sub regency. The number of samples (respondents) of lowland rice farmers selected are 60 people in Sukaraja sub regency. The sample for farmer groups selected is $30 \%$ of all existing farmer groups. Meanwhile, other agribusiness institutions were identified using the snowball method.

\section{Data Analysis Method}

1. Identifying the level of household food security of rice farmers using descriptive methods. In this analysis, the distribution of qualitative data obtained from the field is presented through a codification process, categorization, interpretation, meaning, and abstraction (Meleong, 2004 and Sukandarrumidi, 2004). This descriptive analysis focuses more on the effort to explain the level of food security (food availability, level of stability, access and utilization of food). Food security measurement indicators.

a. Sufficiency of Food Availability

Table 1. Sufficiency of Food Availability

\begin{tabular}{ccc}
\hline Staple Food & Food Stock & Condition \\
\hline \multirow{2}{*}{ Rice } & $\geq 20$ days/month & Secure \\
\cline { 2 - 3 } & $\leq 20$ days/month & Insecure
\end{tabular}

(Research Center for Population -LIPI 2009)

b. Stability of Food Availability

Table 2. Stability of Household Food Availability

\begin{tabular}{ccc}
\hline $\begin{array}{c}\text { Adequacy of Food } \\
\text { Availability }\end{array}$ & Eating Frequency of Household Member \\
\cline { 2 - 3 }$>20$ days & $\geq 3$ times & 2 times \\
\hline $1-20$ days & Stable & Less Stable \\
\hline
\end{tabular}

(Research Center for Population -LIPI 2009) 
C. Accessibility or Affordability of Food

Table 3. Accessibility or Affordability of Food

\begin{tabular}{lll}
\hline \multicolumn{1}{c}{ Land Ownership } & \multicolumn{1}{c}{ Household Obtaining Food } \\
\hline Owned & Direct Access & Secure \\
Others & Direct/Indirect Access & Insecure \\
\hline
\end{tabular}

(Research Center for Population -LIPI 2009)

d. Quality, Safety, and Utilization of Food

Table 4. Quality, Safety, and Utilization of Food

\begin{tabular}{|c|c|c|c|}
\hline No & Details & $\begin{array}{c}\text { Side Dishes Source of } \\
\text { Consumption }\end{array}$ & Conclusion \\
\hline 1 & Consumption & Plant Proteins & Food Insecure \\
\hline 2 & Consumption & $\begin{array}{l}\text { Only Animal Proteins or } \\
\text { Animal and plant Proteins }\end{array}$ & Food Secure \\
\hline
\end{tabular}

(Research Center for Population -LIPI 2009)

2 To analyze the determinants of the level of food security, multiple linear regression analysis was used. Mathematically formulated as follows:

$$
Y=\alpha+\beta_{1} X_{1}+\beta_{2} X_{2}+\beta_{3} X_{3}+\beta_{4} X_{4}+\beta_{5} X_{5}+e
$$

where: Y : Food Security Level (0 or 1) 0 : Insecured 1 : Secured ; : intercept; X1: Land Acre (Ha); X2: Education Level (years); X3: Farming Experience (years); X4: number of family members (person); X5: Farming Income (Rp/F/PS); $\beta$ _1- $\beta$ 5: Regression Coefficient.

3 Analyze the role and performance of rice agribusiness institutions. The analysis used is descriptive statistics. The role of each rice agribusiness institution will be described in detail and in depth. Meanwhile, to measure the performance of each institution based on input and output by realizing the work achievement or program of each rice agribusiness institution. To calculate the performance indicator achievement value (NCIK) using the formula (Santosa, 2005) as follows:

$$
N C I K=\frac{P(\%)}{\sum B S(\%)} \times B S(\%)
$$

where: NCIK: performance indicator value; $\mathrm{P}$ : percentage of institutional program realization; BS: Score; $\sum$ BS: total score.

Based on NCIK calculations, then the performance measurement is determined by using a rating scale so that the institutional performance of rice agribusiness is found: low, medium, and high. To measure the institutional

72 | Sriyoto, Irnad, Bambang Sumantri, Basuki S. Priyono; Food Security and... 
performance of rice agribusiness based on the results (outcomes) and benefits (benefits) used the calculation of rice farming income. Institutional performance is categorized into: low, medium, and high.

To measure the performance of rice agribusiness institutions based on outcomes and benefits, the calculation of rice farm income is carried out using the formula:

$$
I N C=T R-T C
$$

where: TR : Q - P ;TC : VC + FC ;INC : rice farming income (Rp/Ha) ;TR: total revenue $(\mathrm{Rp} / \mathrm{Ha})$; $\mathrm{Q}$ : production $(\mathrm{kg} / \mathrm{Ha})$; P: Price $(\mathrm{Rp} / \mathrm{kg})$; TC: total Production Cost (Rp/Ha) ; VC : Variable Cost (Rp/Ha) ; FC : Fixed cost (Rp/Ha)

Based on the calculation of farm income, the performance of rice agribusiness institutions can then be categorized, namely: 1) poor performance; 2) good performance; 3) high / excellent performance.

\section{RESULTS AND DISCUSSION}

\section{Characteristics of Respondents}

\section{Wetland Rice Farmers}

From the results of the study, it can be seen that a high percentage of farmers who are over 40 years old, this shows that work as rice farmers is rarely carried out by young people in the research area. This situation occurs because some young people in the research area are less interested in working as farmers.

The average formal education that farmers have is 9.8 years or has graduated from junior high school. According to the farmers' admission, at the time of the research, this was due to the economic limitations of their parents before and some thought that their parents were still able to afford education to a higher level, but their parents, especially fathers, thought that if they would take care of the fields and their children later their children they do not need high formal education. Their parents think that only basic skills such as reading and writing are considered to equip them to live in the agricultural world.

The average rice farming experience is 16.4 years. The experience of cultivating lowland rice by farmers will affect their skills and become a farmer in carrying out rice farming activities.

The number of lowland rice farmer family members is an average of 4 people. If it is related to the cost of living necessities that must be spent, it is not big amount because farmers only need to meet the living needs of the farmers themselves, one wife and two children. If it is related to the rice farming income, which is Rp. $11,150,000,-/ 0.8$ ha then this income is sufficient to meet the needs of a family. On average, rice farmers have their own land ownership status, only a few farmers have the status of rental land. This means rice farmers in the research area can rely on 
the agricultural sector to meet the needs of family life through income obtained from rice farming carried out.

\section{Rice Agribusiness Institution}

Conceptually, the agribusiness system is defined as all activities starting from the procurement and distribution of production facilities (input) to the marketing of products produced by farming or the agricultural sector. The agribusiness system includes four subsystems, namely: a) upstream agribusiness; b) farming or primary farming sector; c) downstream agribusiness; and d) supporting services. Because this system is a series of continuous activities from upstream to downstream, the success of agribusiness development is highly dependent on the progress that can be achieved in each subsystem.

The series of activities in agribusiness is driven by various institutions and the role of institutions in the agribusiness system will determine the success of agricultural development in the future. Pakpahan (2000) states that institutions are a requirement for the adequacy of development efforts. The availability of institutional instruments is a sufficient condition because with this instrument, resources can be allocated and mobilized optimally.

The main problem in the development of rice agribusiness is the policy of providing production facilities, especially seeds, fertilizers, pesticides and capital. Currently, the procurement and distribution of rice seeds is still dominated by PT. Sang Hyang Seri (SHS) and PT. Pertani, and only a small portion of the seeds are produced by local private breeders. The growth of private seed breeders who produce unlabelled seeds with sufficient quality and relatively low prices indicates the large potential demand for rice seeds. In general, local private breeders do not have adequate facilities such as: drying, warehouse, and testing equipment. The trend of increasing demand for quality rice seeds at the farmer level, and the volume of rice seeds produced by local private breeders have made the market for rice seeds increasingly competitive.

Based on the research results, it was found that the paddy agribusiness institutions in Seluma Regency such as PT. Pupuk Sriwijaya (PUSRI), PT. Pertani, BRI Bank, and farmer group institutions PT. PUSRI represents an agency that provides fertilizer and its distribution. With the increasingly tight competition in the seed market, the fertilizer market mechanism has also been adjusted. In an effort to create efficiency in fertilizer trading, the government has implemented policies such as: eliminating the difference in fertilizer prices allocated to food crops and plantations, completely removing fertilizer subsidies and eliminating distribution monopolies, and opening up opportunities for new entrants to distributors. PT. Pertani and PT. Sang Hyang Seri (SHS) provides and distributes certified seeds. However, the reality is that in the field there are many private seed breeders and the increasing demand for rice seeds, so that private seed breeders will become competitors for PT. Pertani and PT. SHS in providing rice seeds for farmers. 
In Seluma sub regency, there is a BRI Bank institution that has a role in providing funds to funding the agricultural sector. Farmer group institutions as an integral part of agricultural development have an important role and function in driving agricultural development in rural areas. Farmer group institutions carry out group activities based on group agreement, these activities can be based on the type of business or elements of the agribusiness subsystem such as: procurement of production facilities, agricultural production, post-harvest processing, marketing and so on. The selection of farmers group activities is highly depends on the suitability of interests, natural resources, socio-economy, familiarity, mutual trust and harmony in the relationship between farmers, so that it can be a binding factor for the preservation of group life, where each member can feel ownership and get the maximum benefits from the existence of farmers group.

\section{Analysis of Food Security Level}

Analysis of the level of household food security of rice farmers is analyzed using 4 (four) indicators from FAO (1996) and Law of the Republic of Indonesia No. 8 of 2012, namely the adequacy of food availability, stability of food availability, accessibility or affordability of food and utilization and quality or food security.

\section{Sufficiency of Rice Availability Conditions}

Sufficiency of household rice availability can be seen from how much rice can be stored for household consumption needs for one month or a minimum of 20 days. According to Samantha, et al. (2018) that the sufficient condition of rice food availability is inadequate if the household stores rice for one year as much as $\leq 28$ $\mathrm{kg} /$ year / capita, moderate conditions are $28-42 \mathrm{~kg}$ / year / capita and high or large conditions as much as $>42 \mathrm{~kg}$ / year / capita. Regarding the condition of adequacy of rice availability can be seen in Table 5 .

Table 5. Sufficient Conditions of Rice Availability of Farmers Households

\begin{tabular}{ccccc}
\hline No & $\begin{array}{c}\text { Rice Supply } \\
\text { (days) }\end{array}$ & $\begin{array}{c}\text { Number of } \\
\text { farmers } \\
\text { (person) }\end{array}$ & Percentage (\%) & Conclusion \\
\hline 1 & $<20$ & 17 & 28,33 & Insecure \\
2 & $\geq 20$ & 43 & 71,67 & Secure \\
\hline & Total & 60 & 100 & \\
\hline
\end{tabular}

Source: Processed Primary Data (2020)

Table 5 shows that 71.67 percent of rice farmer households in the study area have sufficient and stable availability of rice or food. or it can be said that $71.67 \%$ of farmer households have rice availability for more than 20 days in a month. In other words, 43 rice farmer households are categorized as food secure. A total of 17 rice farmer households or 28.33 percent are categorized as food insecure. This is in line 
with Rositawati's study (2017), that households have stable food availability, that is, if the percentage of food availability exceeds half of the number of rice farmers studied or more than $50 \%$ of the total rice farmer households have staple food availability for more than 20 days in one month.

Research by Prayitno et al (2019), Suharyanto (2011), and Syawie (2012) found that based on calculations on the aspect of food availability, a value of 57 percent is obtained, which means that it is quite good or food secure. According to Maryani et al (2017), Nurmalina (2008), and Santosa (2017) the results of her research show that the level of rice food availability was obtained at 67.99 percent, which means that its availability is categorized as good enough or food secure.

In the research area, the availability of rice food can be fulfilled for consumption. This is because farmer households practice rice cultivation 2 (two) times a year, with an average area Land of $0.8 \mathrm{ha}$. They also have small family with 2-4 family members and most of them are working members.

The amount of rice stored as consumption in a food-secure condition, that is, if the rice supply is more than $7 \mathrm{~kg}$ per month / capita or more than $84 \mathrm{~kg}$ per year / capita. This condition is in line with Samantha's (2018) research, which states that the adequacy of food availability in most households stores rice more than $84 \mathrm{~kg}$ per year / capita or more than $7 \mathrm{~kg} /$ month / capita. This is because seeing from the activities they carry out it consumes enough energy so that the high frequency of eating causes the stored rice food stock to be high as well.

\section{Stability of Household Food Availability}

The stability of rice food availability in rice farmer households is seen from the percentage of households based on the frequency of eating, which is then combined with the adequacy of food availability to produce an indicator of food availability stability (Rositawati, 2017; Rosyadi and Purnomo, 2012; Nainggolan, 2008; Syaifullah, 2013). Households are said to have stable food availability or secured if the supply of staple food is sufficient and family members eat an average of at least 3 (three) times a day. The farmer household food availability is presented in Table 6.

Table 6. Stability of Household Food Availability

\begin{tabular}{ccccc}
\hline No & $\begin{array}{c}\text { Eating Frequency } \\
\text { (per days) }\end{array}$ & $\begin{array}{c}\text { Number of } \\
\text { Farmers } \\
\text { (Person) }\end{array}$ & Percentage (\%) & Conclusion \\
\hline 1 & $<3$ & 17 & 28,33 & Insecure \\
2 & $\geq 3$ & 43 & 71,67 & Secure \\
\hline & Total & 60 & 100 & \\
\hline
\end{tabular}

Source: Processed Primary Data (2020)

76 | Sriyoto, Irnad, Bambang Sumantri, Basuki S. Priyono; Food Security and... 
Based on Table 6, it shows that the farmer household As many as 43 people or 71.67 percent of rice had a frequency of eating more or equal to 3 (three) times a day and if the combined adequacy of stable food availability, then the household was categorized as food secured. The high frequency of eating in a day is also influenced by the activities of farmers and their families in carrying out farming activities. In the research area, the average working hours of farmers to carry out farming activities and including farmer families starts from 08.00 to 17.00 WIB or in other words, farmers and other family members are on the farm for \pm 8 hours. With full working hours for farming activities, a lot of energy is needed which is high enough and in turn will increase the frequency of meals in a day.

\section{Accessibility or Affordability to Food}

Accessibility indicators in food security at the farm household level can be seen from the ease with which farmer households obtain rice food for consumption. Access to rice food is grouped into 2 (two) categories, namely direct and indirect access. Direct access means that the household owns their own land or how to obtain rice food by producing it themselves, while indirect access means that the household does not own their own land or obtains rice food by buying it.

Farming households are said to be food secured if the method of obtaining rice food is by producing themselves or having direct access, while households are not food secured if the method of obtaining rice is direct or indirect. Households have their own land and produce, but still buy rice for consumption. Regarding accessibility or affordability to household food, farmers can be seen in Table 7.

Table 7. Farmers Household Accessibility or Affordability to food

\begin{tabular}{|c|c|c|c|c|}
\hline No & Obtaining Food & $\begin{array}{l}\text { Number of } \\
\text { Farmers } \\
\text { (Person) }\end{array}$ & $\begin{array}{l}\text { Percentage } \\
\quad(\%)\end{array}$ & Conclusion \\
\hline 1 & $\begin{array}{ll}\text { Directly } & \text { and } \\
\text { Indirectly } & \end{array}$ & 17 & 28,33 & Insecure \\
\hline \multirow[t]{2}{*}{2} & Directly & 43 & 71,67 & Secure \\
\hline & Total & 60 & 100 & \\
\hline
\end{tabular}

Source: Processed Primary Data (2020)

Based on Table 7, it explains that it is 71.67 percent or as many as 43 farmer households are categorized as food secured, because the method of obtaining food directly produces their own and does not interfere with crop failure so that it can meet family needs.

Rice farmer households that are categorized as not secure to food are 28.33 percent or 17 farmer households. Farmers' households that experience food insecurity due to farming experience crop failure due to pests and diseases, lack of water and the use of poor quality seeds. To meet the need for rice food 
consumption, farmer households have to buy rice. The results of the research by Prayitno, et al. (2019) state that the value of food accessibility is said to be not food secured, with a value of 23.91 percent.

\section{Food Quality, Safety and Utilization}

Measurement or indicators of food safety quality, namely by observing whether or not there is a type of protein in daily food consumed by farmer households. The consumption of protein by farmer households is divided into 2 (two) categories, namely animal protein and vegetable protein. Table 8 presents the quality, safety and utilization of farmer household food.

Table 8. Quality, Safety and Utilization of Household Food

\begin{tabular}{ccccl}
\hline No & Source of Consumption & $\begin{array}{c}\text { Number of } \\
\text { Farmers (Person) }\end{array}$ & $\begin{array}{c}\text { Percentage } \\
(\%)\end{array}$ & Conclusion \\
\hline 1 & Animal Proteins Only & 17 & 28,33 & Insecure \\
2 & Animal and Plant Proteins & 43 & 71,67 & Secure \\
\hline & Total & 60 & 100 & \\
\hline
\end{tabular}

Source: Processed Primary Data (2020)

Table 8 explains that 71.67 percent or as many as 43 farmer households have food quality in the food secure category. This indicates that the farmer household has consumed food originating from the consumption of animal and vegetable protein. This condition is supported by the income and purchasing power of the farmer household. The motives of the farmer household to consume these side dishes are more due to the habit that is carried out continuously and affordability. purchasing power of farmer households in accessing food. Hardiansyah, et al (2012) stated that the level of good nutrition consumption is an indicator of a high level of nutritional knowledge which will affect the level of food security.

Farming households in an effort to meet the needs of animal and vegetable protein by cultivating various types of vegetables, tubers and fruits in addition to cultivating rice and some farmer households raising village chickens which are consumed by meat and eggs.

\section{Determinants of Farmers' Household Food Security}

In an effort to maintain the level of household food security of rice farmers (seen from the availability, level of stability, access and quality of food utilization), it cannot be separated from the attributes or characteristics of household resources such as land area, formal education, experience. farming, number of family members, and income. These factors will theoretically determine or influence the level of household food security of farmers. 
To analyze the effect of household resource characteristics on the level of food security, multiple linear regression analysis was used. Regression analysis is an analysis of the influence between the independent variable and the dependent variable. The independent variable is a variable that affects the size of the dependent variable or variable which is a predictor of the dependent variable. In regression analysis, the effect of two or more variables has a stochastic or causal relationship (Sunyoto, 2011). Table 9 presents the estimation results of the determinants of the level of household food security

Table 9. The results of the estimation of the determinants of the level of food security

\begin{tabular}{llrrr}
\hline No & \multicolumn{1}{c}{ Independent Variables } & $\begin{array}{r}\text { Regression } \\
\text { Coefficient }\end{array}$ & $\begin{array}{c}\text { Error } \\
\text { Standard }\end{array}$ & \multicolumn{1}{c}{ t-stat } \\
\hline 1 & Acreage (Ha) & $-0,23143$ & 0,25590 & $-0,9045$ \\
2 & Formal Education (years) & 0,00937 & 0,01531 & 0,6122 \\
3 & Farming Experience (years) & 0,00269 & 0,01050 & 0,2560 \\
4 & Number of Family Member (person) & $-0,21759$ & 0,04885 & $-4,455^{\star *}$ \\
5 & Farming Income (Rp/F/PS) & 0,00008 & 0,00002 & $3,544^{* *}$ \\
6 & Constanta & 0,86840 & 0,34630 & 2,0580 \\
\hline & R & 0,6906 & & \\
& F-calculated & 24,105 & & \\
& F-table & 2,56 & & \\
& T-table $(\mathrm{a}=0,05)$ & 2,009 & & \\
\hline
\end{tabular}

Source: Processed Data (2020)

From the results of the analysis above, it is known that the R2 value of this model is 0.6906 , means that the model used can explain the relationship between the dependent and independent variables by $69.06 \%$, while the rest is influenced by other variables that are not included in the model. Furthermore, the statistical test on the independent variable simultaneously ( $F$-test) that has been carried out shows that the F-calculated value is 24.105 . When compared with the F-table value $(\alpha=0.05)$ which is 2.56, then the F-calculated value> F-table, so that $\mathrm{H} 0$ is rejected and $\mathrm{H} 1$ is accepted. So collectively the variables of land area, formal education, farming experience, number of family members, and farm income that are included in the model affect household food security of farmers in the study location.

To determine the effect of each independent variable on the dependent variable, a partial test (t-test) was used. The results of the t-test on the five independent variables show that only two variables have an effect on household food security. The two variables are the number of family members and the amount of farm income.

The variable of land area has no effect on household food security. This is indicated by the $\mathrm{t}$-calculated value of this variable $(0.9045)<\mathrm{t}$-table $(2.009)$. These 
findings differ from existing theories. Wahed (2015) in his research stated that land area is one of the main factors in increasing rice production which in turn can improve the welfare of rice farmers. However, the role of land area in the amount of rice production in the research location has decreased. This is because the amount of control of farmers over agricultural land is decreasing with the land inheritance system.

The t-calculated value of the formal education variable is $0.6122<$ T-table (2.009). This shows that the variable formal education has no effect on household food security. The results of this study are different from research conducted by Damayanti and Khoirudin (2016). Their research shows that formal education has a positive effect on the level of farmers household food security. This difference occurs because based on data on the characteristics of farmers in the study locations, the education level of each farmer is almost the same. So that there is no significant difference in their farming performance.

Farmers' farming experience in the research location has no effect on farmer household food security. This is proven by the value of t-calculated $(0.2560)<T$-table (2.009). This is because even though farmers already have good abilities in managing their farm, if they cannot manage their family finances properly, it is still difficult to achieve household opportunities for food security.

In contrast to the three previous variables, the variable number of family members shows different results, namely affecting the food security of farmer households. This is indicated by the t-stat value (-4.455)> T-table (-2.009). The number of family members has two distinct sides of influence. On the one hand, more and more family members have the opportunity to burden household finances because they increase consumption. On the other hand, if more family members work, it can increase food security because it makes a positive contribution to household finances. The results of this study are in line with research conducted by Damayanti and Khoirudin (2016). In this study, it is known that the number of family members has a negative effect on household opportunities for food security. Likewise what happened at the research location. The negative sign on the regression coefficient indicates that the greater the number of family members, the lower the household food security of farmers.

The next variable that has influence is farm income. This variable has a value of T-calculated (3.544)> T-table (2.009). The results of this study are in line with research conducted by Damayanti and Khoirudin (2016). In this study, it is known that family income has an effect on household food security. In line with this study, the results of Saputro and Yuli's (2020) research show that the amount of income has an effect on household food security. This is because someone who has a high income will tend to allocate fixed food expenditure and prefers to shift his expenditure allocation to the non-food sector. 


\section{Level of Food Security and Institutional Performance of Rice Agribusiness}

In the discussion will describe the level of food security with agribusiness institutional performance. In theory, there is a link between the level of food security and the performance of agribusiness institutions or the role of agribusiness institutions. The level of food security will run along with the performance of agribusiness institutions, this means that increased food security will be followed by an increase in the performance of agribusiness institutions and the increasingly role of agribusiness institutions (Darus, et. Al. 2019).

From the results of the study, it was found that the level of household food security which was reflected through the availability of food, stability, access and security or utilization in general could be said to be food secure, which was 71.67 percent or in other words the level of farmer household food security was categorized as food resistance. .

This condition is related to the role and performance of the PT. Pusri, where the role of this institution is as a distributor and supplier of fertilizers (urea, TSP, KCL) and the realization of urea and TSP fertilizer distribution has met the target of above 80 percent. It can be concluded that the performance of PT. Pusri is said to be very good, so that the fertilizer needs for farmers can be met. Thus efforts to increase production and productivity can be achieved and will ultimately increase farmers' income.

The role and performance of PT. Farm where this institutional role is as a certified seed supplier. The role of the farmer group can be played at any time by the leader (chairman), as well as by other members. The group leader has the role of coordinator, where they explain or show the relationship between various opinions and suggestions. Besides that, the group leader also acts as a group energizer to act or make decisions and tries to encourage the group to do what has been determined. While each group member is certainly allowed to play more than one role in group participation.

In general, there are 3 (three) things that can indicate the strength of a farmer group, namely: 1) the ability of the farmer group to achieve its goals; 2 ) the ability of farmer groups to maintain groups to keep them congenial, harmonious and balanced, and; 3 ) the ability of farmer groups to develop and change so that they can continue to improve their performance.

The results showed that the role of farmer groups in providing inputs or production infrastructure (seeds and fertilizers) can be said to have only reached 65 percent. Farmer groups as providing capital for farmers have not been fully realized. This is because the farmer group institution does not have a savings and loan business. This condition can be concluded that the institutional performance of farmer groups is categorized as quite good. 


\section{CONCLUSIONS AND POLICY IMPLICATIONS}

\section{Conclusions}

Based on the results of research on the level of food security and institutional performance of rice agribusiness in Seluma district, conclusions can be drawn as follows:

1. The level of household resilience of farmers is categorized as food resistance by 71.67 percent and those that are not resistant by 28.33 percent.

2. The determinants of the level of food security that have influence are the number of family members and the income of rice farming, while those that do not influence are the area of land, formal education and farming experience.

3. Food secure category with institutional performance of PT. PUSRI is very good, PT. Pertani is good, BRI Bank is good, and farmer group institution is fair.

\section{Policy Implications}

In an effort to increase productivity, income and food security, it is hoped that PT. Pertani as a certified seed producer and provider maintains seed quality. The role and performance of farmer group institutions need to be improved in order to achieve a more resilient level of farmer household food security.

\section{REFERENCES}

Damayanti, VL., R. Khoirudin. 2016. Analisis Faktor-faktor yang Mempengaruhi Ketahanan Pangan Rumah Tangga Petani (Studi Kasus: Desa Timbulharjo, Sewon, Bantul). Jurnal Ekonomi \& Studi Pembangunan 17 (2): 89-96

Darus, Fahrial, dan Efendi, RA. 2019. Peran Kelembagaan Agribisnis dalam Rangka Mensukseskan Program Ketahanan Pangan Riau di Kabupaten Rokan Hulu. Jurnal Agribisnis 21 (2): 198 - 211.

FAO. 1996. World Food Summit, 13-17 November 1996. Volume 1, 2, 3.

Hardiansyah, Riyadi, H, dan Napitupulu, V. 2012. Angka Kecukupan Gizi (AKG) Indonesia WNPGX. 2012. Departemen Gizi FK UI. Jakarta

Januar, M dan Sumardjo. 2009. Peranan Kelompok Tani dalam Ketahanan Pangan Rumah Tangga Petani. Jurnal Penyuluhan. 6 (2): 1 - 14.

Mariyani, Siti, Prasmatiwi, Febreanti, E dan Adawiyah R. 2017. Ketersediaan Pangan dan Faktor-faktor yang mempengaruhi Ketersediaan Pangan Rumah Tangga Petani Padi Anggota Lumbung Pangan di Kecamatan Ambarawa, Kabupaten Pringsewu. JIIA. 5 (3): 304-311

Meleong, L.J. 2004. Metode Penelitian Kualitatif Edisi I cetakan ke-18. Resdakarya. Bandung

82 | Sriyoto, Irnad, Bambang Sumantri, Basuki S. Priyono; Food Security and... 
Nainggolan, Kaman. 2008. Ketahanan dan Stabilitas Pasokan, Permintaan, dan Harga Komoditas Pangan. Analisis Kebijakan Pertanian. 6 (2): 114 - 139.

Nurmalina, Rita. 2008. Keberlanjutan Sistem Ketersediaan Beras Nasional: Pendekatan Teknik Ordinasi Rap-Rice dengan Metoda Multidimensional Scaling (MDS). Jurnal Agribisnis dan Ekonomi Pertanian. Vol 2 (2). Page 65 - 88.

Pakpahan, A. 2000.Kerangka Analitik untuk Penelitian Rekayasa Sosial: Evaluasi Kelembagaan Pedesaan di Tengah Perkembangan Teknologi Pertanian. Pusat Penelitian AgroEkonomi. Badan Penelitian dan Pengembangan Pertanian. Departemen Pertanian RI. Bina Laktama Bogor

Prayitno, Gunawan, maufida, B dan Tjahja, A. 2019. Modal Sosial, Ketahanan Pangan dan Pertanian Berkelanjutan Desa Ngadireso.Indonesia Region. 14 (2): 229 243

Rositawati, DFY. 2017. Pemodelan Status Ketahanan Pangan Rumah Tangga Menggunakan Metode Regresi Logistik Biner. Departemen Statistik Bisnis. Institut Teknologi Sepuluh November. Surabaya

Rosyadi, Imron, Didit Purnomo. 2012. Tingkat Ketahanan Pangan Rumah Tangga di Desa Tertinggal. Jurnal Ekonomi Pembangunan 13 (2): 303 - 315.

Sadikin, L, RN. Suhaeti, dan Saradistra, K. 2008. Kajian Kelembagaan Agribisnis dalam Mendukung Pengembangan Sistem Usaha Pertanian Berbasis Agroekosistem. Balai Latihan dan Pengembangan Sosial Ekonomi Pertanian. Badan Litbang Pertanian. Bogor

Salim. 2004. Manajemen Ketahanan Pangan Era Otonomi Daerah dan Peranan Bulog.

Departemen Pertanian. Jakarta

Samantha, Y. Meganti, NS dan Amaliah, L. 2018. Kajian Ketahanan Pangan Rumah Tangga Petani Penggarap The. Jurnal Agrisep. 4 (2): 1151-2550

Santosa, PA, H. Suryadi, Subagyo, dan VI. Beny. 2005. Dampak Teknologi Usaha Pertanian Padi terhadap Peningkatan Produksi dan Pendapatan di Jawa Timur. Jurnal Pengkajian dan Pengembangan Teknologi Pertanian 8 (1): 15 - 28.

Santosa, Sintha Prameswari, Sudrajat. 2017. Kajian Ketersediaan dan Kebutuhan Konsumsi Beras di Kabupaten Karanganyar Jawa Tengah. Jurnal Bumi Indonesia. 6 (4): 1 - 11.

Saputro, Wahyu Adhi, Yuli Fidayani. 2020. Faktor-faktor yang Mempengaruhi Ketahanan Pangan Rumah Tangga Petani di Kabupaten Klaten. Agrica Uurnal Agribisnis Sumatera Utara) 13 (2): 115 - 123

Soekartawai, 1994. IImu Usahatani dan Penelitian untuk Pengembangan Petani Kecil. UI Press. Jakarta

Suharyanto, Heri. 2011. Ketahanan Pangan. Jurnal Sosial Humaniora. Vol. 4 (2). Page 186 - 194.

Sukandarrumidi. 2004. Metode Penelitian Petunjukkan Praktis untuk Penelitian Pemula

Cetakan ke-2. Gadjah Mada University Press. Yogyakarta

Sunyoto, D. 2011. Statistik Deskriptif untuk Ekonomi. Yrama Widya. Bandung

Syaifullah, Yunan. 2013. Ketahanan Pangan dan Pola Distribusi Beras di Provinsi Jawa Timur. Journal of Economics and Policy. 6 (2): 103 - 112. 
Syawie, Mochamad. 2012. Ketahanan Pangan dan Kesejahteraan Petani. Informasi. 17 (3): 158 - 164.

Rusdiana, Supardi, Aries Maeysa. 2017. Pertumbuhan Ekonomi dan Kebutuhan Pangan Indonesia. Jurnal Sosial Ekonomi dan Kebijakan Pertanian. 6 (1): 12 25.

Undang-undang Republik Indonesia Nomor 08 Tahun 2012. Tentang Tingkat Ketahanan Pangan. Accessed from https: //id.wikisource.org/wiki/undangundang Republik Indonesia Nomor: 08 Tahun 2012.

Wahed, Mohammad. 2015. Pengaruh Luas Lahan, Produksi, Ketahanan Pangan dan Harga Gabah terhadap Kesejahteraan Petani Padi di Kabupaten Pasuruan. JESP 7 (1): 68 - 74 